\title{
School Strike 4 Climate (Justice): exploring the experiences of climate strike organisers in Canada
}

\author{
Jayden Wlasichuk \\ Department of Geography, Environment and Geomatics, University of Guelph, Guelph, Canada \\ Email: jwlasich@uoguelph.ca
}

(Received 30 November 2021; revised 17 January 2022; accepted 18 January 2022; first published online 14 February 2022)

Keywords: climate justice; climate strike; Fridays for Future; Climate Strike Canada; School Strike 4 Climate

This thesis explores the understandings and definitions of climate justice from the perspective of climate strike organisers from across Canada and the ways in which climate justice is represented and communicated from the Canadian national organising body, Climate Strike Canada (CSC). The climate strikes in September 2019 were record-breaking, with the September 27 strike becoming the largest act of civil disobedience in Canadian history, at the time (Climate Strike Canada, 2019). While inspired by the Fridays for Future (FFF) movement founded by Swedish teenager, Greta Thunberg, the Canadian branch has created a unique list of demands. CSC calls themselves the overarching network of students, youth, activists and allies working to connect climate action through the Canadian school strike movement (Climate Strike Canada, 2020). Drawing on literature from various fields, including climate justice, racial justice, Indigenous sovereignty, eco-emotions, youth and climate advocacy, and social media advocacy, this research sought to examine climate justice from the perspective of the Canadian climate strike leaders.

The aim of this research is to investigate how the Canadian climate strikers define and practice climate justice through their actions and the strikes across Canada. The research question was: How is climate justice represented, perceived and practiced within the Canadian Climate Strike movement? And it was answered by meeting the following objectives:

Objective 1: Analyze how climate justice is defined and described by CSC through social media.

Objective 2: Examine how the strikers personally define climate justice and view their work as related to regional, national and global climate justice actions.

Objective 3: Investigate the personal motivations and experiences of climate strike organisers from Canada's largest cities and strikes to understand who is engaged in climate justice work, what they are doing and why.

To meet these objectives, I conducted 17 semi-structured interviews with climate strike organisers from 10 different cities between August 2020 and October 2020; I then analysed the CSC Instagram page posts between April 29, 2019 and February 14, 2021. I used a qualitative research approach because it allowed me to use flexible methods and a nuanced approach

\footnotetext{
A thesis submitted for the award of Master of Arts in Geography at the Department of Geography, Environment and Geomatics at the University of Guelph.
}

Supervisor: Dr. Roberta Hawkins, University of Guelph. 
to the data analysis, allowing me to engage with subjective perspectives of participants (McGrath, Palmgren \& Liljedahl, 2019).

Initial findings of this research show four primary themes in the strikers' definitions of climate justice: Indigenous sovereignty, racial justice, economic justice and social justice. Environment and the climate serve as a backdrop in climate justice definitions, rather than as a focal point. There are several other findings identified, including: the climate strikers are highly motivated by their emotions; they use social media as a tool to grow the movement in size and impact; the identities of the strikers impact their personal experiences; and the strikers' actions and goals are highly focused on future generations.

Through analysis of these data, I argue that the climate justice shown by the climate strikers is emotional, action-oriented (in that the work they are doing encourages individual and group actions, and that their movement is focused on acting on the climate crisis), and it is grounded in place and time. I describe their climate justice practices as emotional because the participants relate their actions back to the eco-emotions they experience. These findings reveal the ways in which climate strikers define, practice and ground their climate justice through everyday actions in the climate strike movement.

The literature says that climate justice combines the threats of environmental degradation and climate change with concerns about inequalities perpetuated by climate policy, the unequal distribution of resources and impacts of climate change, and power imbalances to address the unequal and unfair distribution of the impacts of climate change on the world's poorest people (e.g. Almeida, 2019; Schlosberg \& Collins, 2014); and it is often described as the actions of governments and policy-making bodies, with little focus on individuals and activists. The strikers say that climate justice is a movement focused on climate change with an intersectional framework that cannot be achieved without racial, social and economic justice for all peoples, regardless of identity or geography. An area of improvement for the movement noted by participants was representation and inclusion for Black, Indigenous and people of colour (BIPOC) organisers, and increased numbers of male organisers and participants.

The implications and contributions of this research include meeting calls in the literature to better understand climate justice in everyday actions and to examine the impacts of the climate strikes (Chatterton, Featherstone \& Routledge, 2013; S. Fisher, 2015; Martiskainen et al., 2020). Further, this research examined eco-emotions in climate strikers and the role of social media in youth climate advocacy (D. R. Fisher, 2019; Stanley, Hogg, Leviston \& Walker, 2021). Finally, this research calls for further research into the climate strikes across the globe to understand the evolution of the movement in the face of the climate crisis.

Citation and digital source for thesis. Wlasichuk, J. (2021). School Strike 4 Climate (Justice): Exploring the Experiences of Climate Strike Organizers in Canada [Master's thesis, University of Guelph]. University of Guelph the Atrium. https://hdl. handle.net/10214/26356.

Publications arising from the thesis. None.

Acknowledgements. I would like to acknowledge and thank my advisor, Dr. Roberta Hawkins, for her continued support and guidance, and my committee members, Dr. Kate Parizeau and Dr. Noella Gray. Thank you to the members of my research team, and to my friends and family for supporting me throughout this journey.

Financial Support. This research was funded by the SSHRC Insight Grant and the Ontario Graduate Scholarship (OGS).

Conflicts of Interest. The author declares that there is no conflict of interest.

\section{References}

Almeida, P. (2019). Climate justice and sustained transnational mobilization. Globalizations, 16(7), 973-979. DOI 10.1080/ 14747731.2019.1651518. 
Chatterton, P., Featherstone, D., \& Routledge, P. (2013). Articulating climate justice in copenhagen: Antagonism, the commons, and solidarity. Antipode, 45(3), 602-620. DOI 10.1111/j.1467-8330.2012.01025.x.

Climate Strike Canada (2019). Climate Strike Canada - About Us. Retrieved November 18, 2019, from https:// climatestrikecanada.org/our-story

Climate Strike Canada (2020). Climate Strike Canada. Retrieved from https://climatestrikecanada.org/en/home

Fisher, D.R. (2019). The broader importance of \#FridaysForFuture. Nature Climate Change, 9(6), 430-431. DOI 10.1038/ s41558-019-0484-y.

Fisher, S. (2015). The emerging geographies of climate justice. Geographical Journal, 181(1), 73-82. DOI 10.1111/geoj.12078.

Martiskainen, M., Axon, S., Sovacool, B.K., Sareen, S., Furszyfer Del Rio, D., \& Axon, K. (2020). Contextualizing climate justice activism: Knowledge, emotions, motivations, and actions among climate strikers in six cities. Global Environmental Change, 65(October), 102180. DOI 10.1016/j.gloenvcha.2020.102180.

McGrath, C., Palmgren, P.J., \& Liljedahl, M. (2019). Twelve tips for conducting qualitative research interviews. Medical Teacher, 41(9), 1002-1006. DOI 10.1080/0142159X.2018.1497149.

Schlosberg, D., \& Collins, L.B. (2014). From environmental to climate justice: Climate change and the discourse of environmental justice. Wiley Interdisciplinary Reviews: Climate Change, 5(3), 359-374. DOI 10.1002/wcc.275.

Stanley, S.K., Hogg, T.L., Leviston, Z., \& Walker, I. (2021). From anger to action: Differential impacts of eco-anxiety, eco-depression, and eco-anger on climate action and wellbeing. The Journal of Climate Change and Health, 1, 100003. DOI 10.1016/j.joclim.2021.100003.

Jayden Wlasichuk completed her Master of Arts (Geography) from the University of Guelph in 2021, and she holds a Bachelor of Arts (Environmental Governance) (Honours) from the University of Guelph completed in 2019. She was inspired by the September 2019 global climate strikes, and particularly those across Canada, to study climate justice from the perspective of organisers, and she is passionate about youth advocacy and intersections of environmental and human rights. She is currently completing her JD at the Robson Hall Faculty of Law at the University of Manitoba. Email: jaydenwlasichuk@ gmail.com

Cite this article: Wlasichuk, J. (2022). School Strike 4 Climate (Justice): exploring the experiences of climate strike organisers in Canada. Australian Journal of Environmental Education 38, 121-123. https://doi.org/10.1017/aee.2022.4 